\title{
INTERAKCIJSKO-KOMUNIKACIJSKI PROCES U NASTAVI I ŠKOLSKO POSTIGNUĆE UČENIKA***
}

Apstrakt: Razredna klima predstavlja jedan od bitnih faktora koji utiče na školsko postignuće učenika. Kako je reč o kompleksnom fenomenu koji uključuje brojne elemente, fokus u ovom radu stavljen je na interakcijsko-komunikacijski proces u nastavi. Cilj rada je da se kroz teorijsku analizu determinišu elementi interakcijskokomunikacijskog procesa u nastavi koji doprinose poboljšanju školskog postignuća učenika, odnosno sprečavanju školskog neuspeha. Rezultati dosadašnjih istraživanja pokazuju da su u značajnoj meri vaspitni stil nastavnika i interpersonalna komunikacija elementi interakcijsko-komunikacijskog procesa koji utiču na školsko postignuće učenika. Iz tog razloga, u radu se najpre razmatraju ovi elementi, gde se poseban akcenat stavlja na verbalnu i neverbalnu komunikaciju, kao glavne odlike interpersonalne komunikacije u nastavnom procesu. Sledeći deo rada je posvećen prikazu rezultata dosadašnjih istraživanja o nivoima i vrstama interakcijske povezanosti u nastavi i njenog uticaja na školsko postignuća učenika. Zaključuje se da bi u nastavi trebalo da budu zastupljeni demokratski stil rukovođenja i podržavajuće-otvoreno-saradnička komunikacijska klima kroz koje bi nastavnik primereno koristio verbalnu komunikaciju i osvestio važnost praćenja i uvažavanja neverbalne komunikacije kako bi doprineo prevenciji, odnosno sprečavanju školskog neuspeha.

Ključne reči: interakcijsko-komunikacijski proces, nastava, školsko postignuće, razredna klima, školski neuspeh.

\footnotetext{
*1ana.tomcic@gmail.com

Rad je nastao u okviru projekta „Kvalitet obrazovnog sistema Srbije u evropskoj perspektivi“ (KOSSEP) br. 179010, koji finansira Ministarstvo prosvete, nauke i tehnološkog razvoja Republike Srbije
} 


\section{UVOD}

Izučavati nastavu znači upoznati veze i odnose od kojih zavisi veća efikasnost nastave i uspešnost učenika. Istraživanja sprovedena tokom druge polovine 20. veka posvećena su proučavanju efikasnosti nastave, stilova upravljanja odeljenjem, razredne klime, gledišta nastavnika, uspostavljanja interakcije u nastavnom procesu, faktora koji utiču na postizanje boljih međusobnih odnosa između nastavnika i učenika (Bratanić i Maršić, 2004). Aktivni komunikacijski odnos nastavnika i učenika u nastavnom procesu posmatra se kao jezgro stručnog i svrsishodnog delovanja nastavnika (Juričić, 2006). Pod pojmom interakcija nastavnik-učenik podrazumeva se njihovo međusobno delovanje u kome jedni prema drugima zauzimaju stavove kojima obostrano određuju ponašanje (Mustafičić, 2013).

Problem koji se vezuje za istraživanja interakcije nastavnik-učenik jeste njihova usmerenost ka različitim aspektima interakcije (poučavanje, rukovođenje razredom, podrška učeničkoj autonomiji, socio-emocionalni odnos), odnosno njihovo pojedinačno dovođenje u vezu sa školskim postignućem učenika (Šimić-Šašić i Sorić, 2011).

Komunikacija između nastavnika i učenika treba da ima odlike pedagoške komunikacije koja podrazumeva: visok nivo interakcije, razumevanje, otvorenost, interpersonalnost, aktivno slušanje, prisustvo emocija i empatiju (Zukorlić, 2016). Pedagoška komunikacija se osmišljava i organizuje sa ciljem podsticanja razvoja i jačanja ličnosti vaspitanika, usvajanja novih znanja, iskustava i vrednosti. Nastavnik i učenici su nosioci pedagoške komunikacije koju treba da podstiče i usmerava nastavnik. Ovakav vid komuniciranja se ostvaruje sa ciljem da se deluje na učenika i izvrši uticaj na njegovu ličnost, kako bi se na taj način kod njega pobudila 
težnja ka: samousavrašavanjem, samoobrazovanjem, samorefleksijom, samoorganizacijom i samorealizacijom (Jovanović, 2004, prema: Radojević, 2015).

Kvalitetan komunikacijsko-interakcijski odnos sa učenicima pokazuje da je nastavniku stalo do njihovog napretka, čime se jača njihovo samopozdanje, što za krajnji ishod daje povećanje efikasnosti i kvaliteta poučavanja (Mustafičić, 2013). Podržavajuća i topla interakcija sa nastavnikom ima uticaj na učenje, socijalne kompetencije i prilagođavanje školi. Takođe, sigurna vezanost za nastavnika povezana je sa višim školskim postignućem, pozitivnijim odnosom prema školi, većim zalaganjima i učešćima $u$ aktivnostima na času, te samim tim i ređim ponavljanjem razreda (Krstić, 2015). Cilj rada je da se kroz teorijsku analizu determinišu elementi interakcijsko-komunikacijskog procesa u nastavi koji doprinose poboljšanju školskog postignuća učenika, odnosno sprečavanju školskog neuspeha.

\section{INTERAKCIJSKO-KOMUNIKACIJSKI PROCES U NASTAVI}

Nastava, kao kompleksna pedagoška pojava, odvija se u dinamičnom polju međusobno isprepletanih interakcija između nastavnika i učenika. Interakcija nastavnika i učenika zavisi od eksplicitnih i implicitnih normi koje propisuje socijalna zajednica i od karakteristika članova interakcije. Eksplicitne norme podrazumevaju pravila i norme koje određuje društvo kao sistem, dok se implicitne norme ogledaju u podrazumevajućim, prećutnim pravilima koja ponekad mogu biti izvor konflikata i predstavljaju pojedinačne norme, za razliku od eksplicitnih koje su opšteprihvaćene. Karakteristike nastavnika su determinisane profesijom, odnosno ulogom koju 
imaju u nastavnom procesu, ali predstavljaju i lični pečat nastavnika, dok su karakteristike učenika razvojno promenljive (Kostović, 2005).

Komunikacijsku razrednu klimu pojedini autori definišu kao „posebnu vrstu socijalnih odnosa u razredu, izraženu kroz oblike komunikacije nastavnika i učenika, prožetu njihovim emocionalnim vezama koje vode ka trajno dobrim rezultatima u učenju“ (Ivanek, Musić, Mikić i Džbirić, 2011: 61). U relevantnoj pedagoškoj literaturi razlikuju se dve vrste razredne klime koje određuju komunikacijski proces između nastavnika i učenika u nastavnom procesu: defanzivno-preteća i podržavajuće-otvorenosaradnička. Defanzivno-preteća podrazumeva međusobno ocenjivanje, kontrolisanje, strateško dirigovanje, bez empatije (neutralno) ponašanje, superiorno nadmetanje bez međusobnog poverenja. Podržavajuće-otvorenosaradnička klima podrazumeva onu klimu u kojoj prepoznajemo problem, spontano se ponašamo, razvijamo empatiju, ravnopravan odnos među sagovornicima, negovanje međusobnog poverenja (Brajša, 1994, prema: Ivanek, Mikić i Karabašić, 2012).

Da bismo razumeli važnost izučavanja i uspostavljanja kvalitetnog interakcijsko-komunikacijskog procesa neophodno je prvenstveno proučiti elemente koji utiču na njihovo kreiranje, a to su: vaspitni stil nastavnika i interpersonalna komunikacija, u okviru koje podjednaku pažnju zaslužuju verbalna i neverbalna komunikacija.

\section{Vaspitni stil nastavnika}

Istraživanja Hjuita pokazuju da je kvalitet interakcije između nastavnika i učenika jedan od najboljih indikatora školskog postignuća učenika, odnosno nivoa učeničke aktivnosti i angažovanja u nastavi i učenju, 
te da ishodi učenja utiču na karakteristike ličnosti i na njihovu motivaciju. Kvalitet interakcije nastavnik-učenik zavisi od nastavnikovog vaspitnog stila (Huitt, 2003; Grasha \& Yangarber-Hicks, 2000, prema: Zukorlić i Osmanlić, 2017). Vaspitni stil nastavnika se određuje kao ,interakcija didaktičkih i vaspitnih kompetencija nastavnika kojima on kreira klimu (atmosferu, ambijent) u nastavi““ (Kostović, 2005: 71).

Vaspitni stil nastavnika se u različitim istraživačkim kontekstima prikazuje bipolarno, kroz sledeće dihotomije:

- u stilu rukovođenja: autoritarni ili demokratski stil,

- u stilu komunikacije: direktivni ili nedirektivni stil,

- u nastavnom stilu: normativni stil ili stil usmerenosti na rešavanje problema,

- $\quad \mathrm{u}$ afektivnom stilu: stil pozitivne emocionalne atmosfere ili negativne emocionalne atmosfere (Kostović, 2005:71).

Prve dve dihotomije su od posebnog značaja za izučavanje date problematike. Autoritarni stil rukovođenja podrazumeva da je u centru svih aktivnosti nastavnik, od kojega potiču sve inicijative i to najčešće u formi prisile, dok učenici imaju male mogućnosti za samostalne aktivnosti, te se njihove reakcije ogledaju u nezadovoljstvu i otporu. Demokratski stil odlikuje nastavnika koji je spreman da sarađuje sa učenicima i da zajednički sa njima postiže ciljeve. Kroz raspravu i dogovaranje nastavnik zajedno sa učenicima određuje cilj, zadatke i odgovarajuće aktivnosti, podstiče učenike na razmišljanje, donošenje odluka bez dominacije i kompeticije. U stilu komunikacije razlikuju se direktivni i nedirektivni stil. Sa jedne strane, direktivni stil se odnosi na predavanja, davanje objašnjenja, usmeravanje 
ponašanja i aktivnosti učenika, kritiku i povezivanje nastavnika na sopstveni autoritet. Sa druge strane, u svom odnosu sa učenicima, nedirektivni nastavnici ispoljavaju veći stepen fleksibilnosti i svoje oblike ponašanja usklađuju sa individualnim svojstvima učenika i datom vaspitnom situacijom. Nedirektivni stil definisan je pohvalama, ohrabrenjima, pozitivnim emotivnim odnosima prema učenicima, drugim rečima, zainteresovanošću nastavnika za osećanja učenika i prihvatanje učeničkih ideja i predloga (Kostović, 2005; Lalić-Vučetić, 2008). Rezultati istraživanja autorke Bratanić, kao i autorke Ševkušić-Mandić, ukazuju na to da je nedirektivni stil nastavnika povezan sa češćim ispoljavanjem inicijative učenika $u$ komunikaciji tako što su oni spremniji da izraze sopstveno mišljenje, postavljaju pitanja i iniciraju komunikaciju (Bratanić, 1986; ŠevkušićMandić, 1992, prema: Lalić-Vučetić, 2008). U skladu sa tim su i rezultati drugih istraživanja koji su ukazali na to da je za ishode učenja učenika delotvorniji nedirektivni stil komunikacije nastavnika, za razliku od direktivnog stila koji pasivizuje učenike kroz sputavanje njihove inicijative, ali i neuvažavanje njihovog mišljenja i njihovih ideja (Zukorlić i Osmanlić, 2017).

Interpersonalna komunikacija u nastavnom procesu

U nastavi postoje različiti oblici komunikacije: komunikacija između dve osobe, tzv. dijadička, koja se javlja u odnosu nastavnik-učenik i učenikučenik, komunikacija u manjim grupama, koja se javlja tokom grupnog oblika nastavnog rada, organizacijska i javna komunikacija, koja se javlja prilikom određenih svečanosti i komunikacija masmedijima. Ono što je karakteristično za sve navedene oblike komunikacije jeste da imaju karakteristike interpersonalne komunikacije koja ima sledeće odlike: 
- interpersonalna komunikacija uključuje verbalno i neverbalno ponašanje,

- interpersonalna komunikacija uključuje spontano, formalno ili konstruktivno ponašanje, odnosno njihovu kombinaciju,

- interpersonalna komunikacija nije statična, već dinamična,

- interpersonalna komunikacija uključuje personalnu povratnu informaciju, interakciju i usklađenost,

- interpersonalna komunikacija vođena je unutrašnjim i spoljašnjim porivima,

- interpersonalna komunikacija je aktivnost,

- interpersonalna komunikacija uključuje uveravanje (Reardan, 1987, prema: Kostović, 2005: 32-33).

Kada se govori o interpersonalnoj komunikaciji misli se istovremeno i na verbalnu i neverbalnu komunikaciju. Verbalna komunikacija je pod većim stepenom kontrole svesti, dok neverbalna predstavlja dopunu i podršku verbalnoj komunikaciji, služeći za izražavanje emocija, stavova i osobina ličnosti (izraz lica nastavnika, usmerenost pogleda, klimanje glavom kao znak ohrabrenja, mrgođenje, nezainteresovanost) i razvija se učenjem (Kostović, 2005).

\section{Verbalna komunikacija u nastavnom procesu}

Ličnost se razvija kroz interakciju sa drugima, što je posebno značajno za lični razvoj učenika. U školama je još uvek u većoj meri zastupljena jednosmerna komunikacija u kojoj nastavnik ima ulogu glavnog organizatora, kreatora i realizatora svih aktivnosti. Ovakav stil nastavnika 
umnogome otežava dvosmernu komunikaciju zbog čega pedagoški monolog nastavnika dominira u vremenskom kvantumu (Kevereski, 2011). Rezultati istraživanja autora Prušević-Sadović i Šehović ukazuju na to da nastavnici veći deo časa provode u verbalnom izlaganju i opisivanju predmeta učenja, ne ostavljajući pritom dovoljno vremena učenicima za pitanja i samostalnu aktivnost u procesu sticanja znanja. Učenička verbalna aktivnost je skromna, reproduktivnog karaktera i nedovoljno česta (Prušević-Sadović i Šehović, 2017). Današnja škola zahteva inoviranje ukupnog komunikacijskog diskursa jer je njena perspektiva da bude progresivan model gde se uče i formiraju osnovni komunikacijski oblici ponašanja. Komunikacija u školi se posmatra kao dijadni odnos, odnos koji uključuje reči, misli, osećanja, percepcije očekivanja i reakcije. Treba insistirati na okretanju škole ka (de)kodiranju neverbalnih simbola i ekspresija koje nam šalju učenici u svakodnevnim interakcijskim odnosima, jer suštinu komunikacije čini $25 \%$ verbalne komunikacije i više od $65 \%$ neverbalne komunikacije. Škola treba da bude dinamičan kompozit interakcijskih odnosa gde komunikacijske interpersonalne refleksije pulsirajući daju život (Kevereski, 2011).

Uspešnu verbalnu komunikaciju ostvariće nastavnik koji:

- poznaje sposobnosti i kognitivne karakteristike svojih učenika, te na taj način obezbeđuje formulaciju nastavnih poruka,

- otklanja sve ometače pažnje: fizičke (buka, prejaka svetlost), kognitivne (poruke koje nisu vezane za predmet ili nastavni sadržaj), socijalne (pojedine socijalne procese i aktivnosti u odeljenju i sl.),

- jasno formuliše svoj iskaz, izbegava tzv. ,podrazumevanje“ u svojim iskazima, posebno u zahtevima koje postavlja učeniku, 
- pokušava da uskladi značenja koja pojmovima on sam pripisuje sa značenjima koja su prihvatili učenici, tako što će povremeno proveravati da li naučni pojmovi koji se usvajaju u nastavi imaju podjednaka značenja za sve aktere (,,Šta za vas znači? Pod tim podrazumevam?“"),

- prepoznaje svoju psihološku pozadinu u komunikaciji (predrasude, očekivanja, strahove, akutne i/ili relativno trajne emocije), kao i psihološku pozadinu u komunikaciji svojih učenika,

- $\quad$ izgrađuje strategije fokusiranog i usmerenog izlaganja, poruka zasnovanih na dobrom poznavanju sadržaja i načina njegovog izlaganja, rukovodeći se zahtevima formulisanja razumljive poruke,

- izgrađuje i čini stalno otvorenim sve komunikacione kanale prema učenicima: vertikalne, ali i horizontalne između učenika, kao i svih aktera u učionici (Zlatić i Bjekić, 2004: 332, prema Radojević, 2015: 44-45).

U nastavnom radu nastavnik ima mogućnost da primenjuje niz metoda kako bi podstakao razvoj sposobnosti verbalne komunikacije učenika:

- $\quad$ metode za direktno razvijanje sposobnosti (interaktivno učenje i sokratovska metoda),

- metoda kultivisanja kreativnosti i rešavanja problema,

- metoda grupnog rada i grupnog razumevanja,

- metoda zapažanja interakcije u sklopu grupe,

- metoda saopštavanja ekipe (Ion-Ovidiu, 2002:140, prema, Radojević, 2015: 45-46). 
Podsticanjem na verbalnu aktivnost učenika menja se odnos $\mathrm{u}$ nastavnom procesu, aktivnost se pomera sa nastavnika na učenika, time proces poučavanja prerasta $u$ proces učenja. Na ovaj način se stvara atmosfera $\mathrm{u}$ kojoj učenik stiče sigurnost i samopouzdanje da govori, povećava svoje govorne kapacitete, jača rečnik, razvija veštinu izlaganja, artikulacije pitanja i odgovora (Prušević-Sadović i Šehović, 2017).

\section{Neverbalna komunikacija u nastavi}

Ljudska bića koriste neverbalnu komunikaciju kako bi obogatila interpersonalnu interakciju, oslanjaju se na neverbalno ponašanje kako bi procenili kada i na koji način treba govoriti, kada treba dopustiti drugima da govore. Neverbalna komunikacija je često odraz kulturnog nasleđa. Ova činjenica implicitno ukazuje na to da se u velikom broju slučajeva neverbalne komunikacione veštine stiču tokom socijalizacije i potpuno su promenljive $\mathrm{u}$ zavisnosti od kulture i tradicije (Bambaeeroo \& Shokrpour, 2017). Neverbalna komunikacija je obogaćena tehnikom aktivnog slušanja koja odražava nastavnikov odnos prema učenicima i sopstvenoj profesiji. Aktivno slušanje obezbeđuje učeniku povratnu informaciju da ga nastavnik razume (Kostović, 2005). Neverbalni znakovi često otkrivaju nameru pošiljaoca informacija i odražavaju njegove emocionalne reakcije. U okviru neverbalne komunikacije akcenat se stavlja na emocije, timski rad, podršku, maštovitu i kreativnu komunikaciju putem tela i slike, kao efikasne načine komunikacije koji doprinose boljem školskom postignuću. Takođe, nastavnici pažnju usmeravaju na neverbalne reakcije učenika i uređivanje nastavnog plana i 
programa u skladu sa raspoloženjem i spremnošću učenika (Bambaeeroo \& Shokrpour, 2017).

Neverbalna komunikacija je često suptilnija i efikasnija od verbalne i može da prenese značenje bolje od reči. Na primer, osmeh ili tihi govor mogu da pokažu stepen razumevanja i podrške među sagovornicima. Prema nalazima pojedinih autora (Farhangi, 1995, prema: Bambaeeroo \& Shokrpour, 2017), u toku razgovora samo 7\% pojmova je izraženo u obliku izgovorenih reči. Veći deo informacija se prenosi kroz kompleksnu kombinaciju izgleda, držanja, pokreta udova, vida i izraza lica. Govor tela ima moć prenošenja stavova i osećanja drugima i u mnogim slučajevima može biti efikasniji od verbalnih poruka (Farhangi, 1995, prema: Bambaeeroo \& Shokrpour, 2017).

Autor Benzer ispitivao je nastavnike o značaju i upotrebi neverbalne komunikacije u nastavnom procesu i dobio sledeće rezultate: $46 \%$ nastavnika je izjavilo da neverbalna komunikacija podržava komunikaciju između nastavnika i učenika, 32\% njih da neverbalna komunikacija podržava motivaciju učenika za temu izučavanja, 20\% nastavnika je reklo da neverbalna komunikacija podstiče učenike da izrađuju materijale za učenje, a 6\% njih da neverbalna komunikacija jača učeničko samopouzdanje. 100\% ispitanika je odgovorilo da nisu imali obuke ili treninge upotrebe neverbalne komunikacije tokom sopstvenog inicijalnog obrazovanja, te da su se nedostaci ove obuke videli kroz prve godine rada sa učenicima, dok su se ovi nedostaci sa povećanjem iskustva smanjili. Na pitanje na koji način uspostavljaju neverbalnu komunikaciju sa svojim učenicima $82 \%$ nastavnika je odgovorilo da sa učenicima uspostavlja očni kontakt, 16\% njih da podiže obrvu, $10 \%$ to čini korišćenjem ruke, $8 \%$ upotrebom facijalne ekspersije, $6 \%$ 
dodirivanjem, a 4\% njih tako što prilazi učenicima i 6\% nastavnika je reklo da to čini klimanjem glave. $96 \%$ nastavnika smatra da njihov način oblačenja ostavlja utisak na učenike i da zauzima dobar deo neverbalne komunikacije, dok njih 4\% smatra da to nije bitno (Benzer, 2012).

Pravilna upotreba neverbalnog govora $u$ nastavnom procesu podrazumeva da se nastavnik nalazi na mestu u učionici gde ga učenici mogu videti, što znači da nastavnik ne sme biti iza katedre ili okrenutih leđa. $\mathrm{Ne}$ treba da drži ruke u džepovima, niti prekrštene, jer to ograničava njegovu slobodu i čini ga nedostupnim u očima učenika. Najbolje je da nastavnik drži slobodne ruke, jer na taj način ukazuje na spremnost u ostvarivanju komunikacije sa učenicima. Nastavnik treba nekoliko puta u toku časa da promeni mesto stajanja, ali ne prečesto, jer će se fokus sa sadržaja i učenja premestiti na kretanje nastavnika. Sledeći bitan element neverbalne komunikacije podrazumeva uspostavljanje kontakta sa učenicima, kako sa pojedinim učenikom tako i sa celom grupom. Nastavnik ne treba prstom da upire u učenika jer može izazvati strah i neprijatnost, već treba da mu se obrati ispruženim dlanom ukoliko postoji potreba za time. Što je prirodniji, neverbalni govor ostvaruje bolje efekte (Farhangi, 1995, prema: Bambaeeroo \& Shokrpour, 2017).

Autorka Šams sa saradnicima predlaže sledeće preporuke za upotrebu neverbalne komunikacije upućene nastavnicima, koje će biti u funkciji boljih obrazovnih postignuća:

- nastavnik treba redovno da koristi neverbalnu komunikaciju na času kako bi mu se učenici mogli približiti i postaviti pitanja, 
- nastavnik treba da koristi neverbalnu komunikaciju kako bi pružio učenicima efikasne odgovore, jer kada nastavnik podstiče učenike na komunikaciju jača njihovo samopouzdanje i odvažnost,

- nastavnik treba da koristi neverbalnu komunikaciju kako bi dobio odgovore od učenika,

- nastavnik treba da koristi neverbalnu komunikaciju kako bi kreirao zdravo okruženje,

- nastavnik treba da koristi neverbalnu komunikaciju za bolje podučavanje,

- $\quad$ nastavnik treba da odredi kvalitet glasa koji će koristiti, a koji će olakšavati učenicima praćenje i učenje,

- nastavnik treba da koristi neverbalnu komunikaciju kako bi objasnio različite predmete i pojave,

- nastavnik pomoću neverbalne komunikacije treba da učini učenje zanimljivim,

- nastavnik treba da koristi klimanje glavom kako bi podržao i aktivirao učenike,

- nastavnik treba da ostvari kontakt očima kako bi ohrabrio učenike u nastavnom procesu (Shams, Khan, Zainab, Shah \& Farid, 2016: 64).

Konstruktivno rešavanje problema u učionici zahteva dobro razvijene veštine neverbalne komunikacije. Upotrebom ove veštine nastavnici mogu igrati glavnu ulogu u uspehu svojih učenika. Upotrebom neverbalnog govora nastavnici skreću pažnju učenika na veće razumevanje predmeta izučavanja i motivišu ga na učenje, ali i podstiču učenika kojima je manje zanimljivo na času. Na taj način učenici nesvesno primaju neverbalne signale od 
nastavnika, istovremeno primećujući kakav odnos nastavnik gradi sa njima (Bambaeeroo \& Shokrpour, 2017). Nastavnik mora neprestano gledati, slušati, osećati, videti, primetiti, posmatrati, misliti, zaključivati i tražiti znakove da li učenik želi i da li može komunicirati. Učenici spremnije ispoljavaju neverbalne znakove, nego verbalne, te nastavnik mora biti spreman da ih prepozna i prihvati (Mustafičić, 2013).

\section{INTERAKCIJA U NASTAVI I ŠKOLSKO POSTIGNUĆE UČENIKA}

Način na koji nastavnici komuniciraju sa učenicima jedan je od značajnih faktora koji pomaže u određivanju efikasne nastave, način na koji učenici percipiraju komunikaciju nastavnika može uticati na njihovo efikasno i kognitivno učenje, na njihov osećaj tokom učenja (Sutiyatno, 2018). Nastavnik svojim radom stvara odnose sa učenicima, komunicira sa njima, određuje oblike komunikacije i nivo učestvovanja učenika u nastavi (Božić, 2015). Autorka Bratanić identifikovala je četiri nivoa interakcijske povezanosti:

- nivo fizičke prisutnosti - predstavlja najniži nivo interaktivne povezanosti u kojoj nastavnik uspostavlja prvenstveno neverbalnu komunikaciju sa učenicima (svojim prisustvom) koja prethodi verbalnoj komunikaciji. Ukoliko nastavnik neverbalnu komunikaciju realizuje površno i nezainteresovano, interakcija ostaje na najnižem nivou,

- akcijsko-reakcijsko komuniciranje pitanje-odgovor - predstavlja onaj stepen povezanosti koji nastaje kada nastavnik, ukoliko je uspostavio verbalnu komunikaciju sa učenicima, aktivira učenike postavljanjem pitanja, 
- empatijsko komuniciranje - uspostavlja se kada nastavnik dobro poznaje svoje učenike i kada način komuniciranja prilagođava njima.

Ovaj nivo komunikacije uglavnom inicira nastavnik. Na ovom nivou se otvara mogućnost da nastavnik utiče na učenikove stavove i vrednosti i podstiče ga na aktivnost. Ovaj tip komunikacija ulazi dublje u učenikovu psihu i odražava se na njegovo zadovoljstvo ostvaruje se vaspitno delovanje,

- dijalog - predstavlja onaj nivo ineterakcije povezanosti tokom koje empatijsko komuniciranje obostrano i kada se postižu najbolji vaspitni efekti, a to podrazumeva da nastavnik i učenik znaju empatijski saslušati jedan drugog, postaviti se na tuđi položaj i problem sagledati sa njegovog stanovišta (Bratanić, 1990, prema: Zukorlić i Osmanlić, 2017: 175).

Interakcija između nastavnika i učenika će biti kvalitetnija ukoliko nastavnik nastoji da dostigne više nivoe interakcijske povezanosti. U kontekstu uticaja nastavnika na ishode učenja kvalitet interakcije koju nastavnik ostvaruje sa učenicima dovodi se u najužu vezu sa učenjem (ŠimićŠašić, 2011). Rezultati istraživanja upućuju na činjenicu da se stručnost nastavnika, njegove osobine, vrednosni sistem, emocionalna stabilnost, način komunikacije sa učenicima pokazuju kao značajan faktor koji može da oteža ili olakša razvoj učenika, uspori ili ubrza proces učenja, da pozitivno ili negativno utiče na njegov socijalni razvoj. Drugim rečima, nastavnik znatno utiče ne samo na proces usvajanja znanja i razvoj sposobnosti, nego i na odnos učenika prema učenju, stavove prema vrednostima i njihovo interesovanje (Kostović, 2005). Rezultati istraživanja pokazuju da postoji 
povezanost između nastavnikovih verbalnih i neverbalnih komunikacijskih veština i motivacije i učenja učenika. Nejasnoća u nastavnikovom govoru i ponižavajući govor su prepoznati kao glavne prepreke u odnosu između nastavnika i učenika (Babelan, 2012; Gholipour, 2007, prema: Bambaeeroo \& Shokrpour, 2017). Rezultati istraživanja su pokazali da nastavnici podjednako primenjuju verbalnu komunikaciju u radu sa neuspešnim i uspešnim učenicima, ali da je razlika prisutna u ophođenju prema neuspešnim učenicima, kada nastavnik koristi neverbalnu komunikaciju. $\mathrm{Na}$ taj način neverbalna komunikacija ukazuje na negativna osećanja koja postoje kod nastavnika, ali i kod učenika (Brophy, 1981, prema: LalićVučetić, 2008). Umesto toga, nastavnik treba da ima ohrabrujuće reči i postupke za sve učenike (Bambaeeroo \& Shokrpour, 2017). Stvarnost učenikovog okruženja tokom nastave često je označena uznemirenošću uzrokovanom strahom od neuspeha. Ova uznemirenost se može prepoznati po boji lica (najčešće bledilo), drhtanju tela i prstiju ruku, zamuckivanju, glavobolji, vrtoglavici, bolovima u stomaku i slično. Prisutnost izraženog straha od neuspeha tokom ispitivanja i ocenjivanja izaziva nesigurnost i nespremnost u oblikovanju odgovora, što može navesti učenika na pogrešne odgovore, dekoncentraciju i otežano prisećanje (Juričić, 2006; Grgin, 1999, prema: Jagić i Juričić, 2006). Iz tog razloga je važno da nastavnik razvije sposobnost prepoznavanja neverbalnih poruka koje učenici šalju. Kada je u pitanju interakcija između nastavnika i učenika, možemo govoriti o značaju pozitivne i negativne interakcije za školsko postignuće učenika. Pozitivnu interakciju karakterišu visoka podrška i visoki izazov koje nastavnici pružaju učenicima uz primenu strategije aktivnog poučavanja. Sa druge strane, nastavnik koji ostvaruje negativnu interakciju sa učenicima pruža nisku podršku i niski izazov, primenjuje autoritarni stil rukovođenja, poseduje 
negativan stav prema poučavanju i visoka očekivanja od učenika (ŠimićŠašić, 2011). Rezultati istraživanja Šimić-Šašić i Sorić ukazuju na to da kvalitet interakcije nastavnik-učenik deluje indirektno preko individualnih karakteristika učenika na ponašanje učenika, a samim tim i na njegovo školsko postignuće. Naime, rezultati su pokazali da pozitivna interakacija više koristi učenicima kojima je potreban viši stepen pomoći u učenju od strane nastavnika. Sa druge strane, učenje devojčica je u većoj meri samoregulisano, te se one znatno bolje snalaze u kontekstu negativne interakcije. Međutim, negativna interakcija ih vodi ka izraženijoj ispitnoj anksioznosti. S tim u vezi, autorke su zaključile da ponašanje učenika zavisi od individualnih karateristika (pol, verovanje o kontroli, motivacione orijentacije, samoefikasnost) koje zavise od kvaliteta interakcije nastavnikučenik (Šimić-Šašić i Sorić, 2011).

$\mathrm{Na}$ osnovu teorijske analize Zibar-Komarica izvodi zaključak da emocionalni razlozi čine dve trećine svih uzroka školskog neuspeha, odnosno 65\% uzroka, dok jednu trećinu (20\%) čine specifične teškoće pri učenju (motorni nemir, usporena motorika, smanjena koncentracija), 10\% teškoća povezane su sa intelektualnim sposobnostima i ostali uzroci iznose 5\% (Zibar-Komarica, 1993). Nedostatak kvalitetne komunikacije, verbalne i/ili neverbalne, može doprineti smanjenju sposobnosti usmenog i pismenog izražavanja, samorazumevanja i analitičkog mišljenja (Healy, 1998, prema: Radojević, 2015).

Celokupni proces vaspitanja kojim se želi uticati treba da se zasniva na sledećim principama pedagoške komunikacije: princip uvažavanja i prihvatanja ličnosti učenika i njegovih osećanja, princip ravnopravne i nenasilne komunikacije između nastavnika i učenika, princip svrsishodnosi 
pedagoške komunikacije, princip aktivizacije učenika u pedagoškoj komunikaciji, princip altruizma i empatičnosti u pedagoškoj komunikaciji, princip uvažavanja kulturalne raznolikosti u pedagoškoj komunikaciji (Zukorlić, 2016: 100). Dobri socijalni odnosi sa vršnjacima i nastavnicima doprinose tome da se pojedinac oseća prijatno i prihvaćeno u školi, da lakše prihvata školske obaveze i da je motivisan da ih ispuni, da ima poverenje $u$ svoje sposobnosti. Drugim rečima, osećanje prihvaćenosti i emocionalne sigurnosti usko je povezano sa akademskom motivacijom (Spasenović, 2004). Iz tog razloga se preporučuje nastavnicima da poboljšaju svoje komunikacione veštine kako bi imali bolju komunikaciju sa učenicima (Bambaeeroo \& Shokrpour, 2017). U tom pogledu, autori Zukorlić i Osmanlić ističu najmanje dve oblasti kroz koje se može uticati na poboljšanje kvaliteta komunikacije između nastavnika i učenika: veštine komunikacije bi trebalo da budu primarni kriterijum za izbor nastavnika, procena veštine komunikacije trebalo bi da bude deo redovne evaluacije nastavnika (Zukorlić i Osmanlić, 2017: 179). Jedan od načina za postizanje ovog cilja jeste organizovanje obuka stručnog usavršavanja nastavnika iz ove oblasti (Bambaeeroo \& Shokrpour, 2017).

\section{ZAKLJUČAK}

Školski neuspeh je kompleksan problem za čije rešenje ne postoji jedinstven postupak, već je ključ u individualnom pristupu učenicima, praćenju njihovog rasta i razvoja, uspostavljanju odnosa poverenja i kontinuiranoj motivaciji. Nastavnik treba da učenicima postavlja zadatke $u$ skladu sa njihovim mogućnostima, pokazujući da je svestan njihovih sposobnosti, istovremeno podstičući njihovu motivaciju i pokazujući im da je voljan da reše problem zajedničkim snagama (Bambaeeroo \& Shokrpour, 
2017). Da bi se u ovim nastojanjima uspelo, potrebno je da komunikacija između nastavnika i učenika bude zasnovana na osnovnim principima vaspitnog rada i opštim principima uspešne komunikacije: poruke koje nastavnici šalju učenicima treba da budu pedagoški zasnovane i artikulisane, u sadržajnom pogledu, poruke treba prilagoditi mogućnostima učenika - da se znakovima kojima komuniciraju nastavnici i učenici daju ista značenja, zahtevi i zadaci upućeni učenicima treba da budu pravilno usmereni, nastavnikovo ophođenje prema učenicima mora biti pedagoški artikulisano i visokoetično, a ne strogo formalizovano (Jovanović, 2004, prema: Zukorlić, 2016: 97). Pedagoške implikacije sprovedene teorijske analize ogledaju se u preporukama uspostavljanja interakcijsko-komunikacijskog procesa $\mathrm{u}$ funkciji povećanja efikasnosti nastave. Da bi nastavnik ostvario dobar odnos sa učenicima, koji će se reflektovati na efikasnost nastave, u nastavi bi trebalo da budu zastupljeni demokratski stil rukovođenja i podržavajućeotvoreno-saradnička komunikacijska klima kroz koju je moguće iniciranje viših nivoa interakcijske povezanosti, kao i primereno korišćenje verbalne komunikacije. Takođe, od izuzetnog je značaja da nastavnik bude svestan važnosti praćenja i uvažavanja neverbalne komunikacije, koja u određenim situacijama može doprineti boljem razumevanju učenikovog ponašanja i ostvarenog postignuća.

\section{TEACHER-STUDENT INTERACTION AND THE SCHOOL FAILURE}

\section{Abstract}

The classroom climate is one of the most important factors influencing the school achievement of students within the teaching process. As this is a complex phenomenon, which includes numerous elements, the focus of this paper is on the interaction-communication process in teaching. The aim of the paper is theoretical 
analysis of elements that influence the occurrence of the school failure within the interaction-communication process in teaching. The results of previous research show that the educational style of teachers and interpersonal communication significantly contribute to the occurrence of the school failure. For this reason, the paper first considers these elements, where a special emphasis is placed on verbal and non-verbal communication, as the main features of interpersonal communication in the teaching process. The next part of the paper is dedicated to the presentation of results of previous research on the relationship between the quality of teacherstudent interaction and the student failure. It is concluded that teaching should be governed by a democratic leadership style, a supportive-open-cooperative communication climate where the teacher uses verbal communication appropriately, and realizes the importance of monitoring and respecting non-verbal communication in order to contribute prevention of the school failure.

Key words: classroom climate, interaction, school failure, student, teacher. 


\section{REFERENCE}

Bambaeeroo, F., \& Shokrpour, N. (2017). The Impact of the teachers' nonverbal communication on success in teaching. Journal of Advances in Medical Education \& Professionalism, 5(2), 51-59.

Benzer, A. (2012). Teachers' opinions about the use of body language. Education, 123(3), 467-473.

Božić, B. (2015). Stvarno i poželjno razredno ozračje u osnovnoj školi. Život $i$ škola, LXI (1), 93-100.

Bratanić, M., i Maršić, T. (2004). Relacije između gledišta učenika o nastavniku i uspjeha u učenju. Napredak, 145(2), 133-144.

Ivanek, P., Musić, H., Mikić, B., i Džbirić, Dž. (2011). Razredna klima u funkciji stvaranja kvalitetne komunikacije i interakcije u nastavi. Sportski logos, 9(16-17), 59-63.

Ivanek, P., Mikić, B., i Karabašić, J. (2012). Razredna klima kao faktor sukoba u komunikaciji između učenika i nastavnika. Sportske nauke $i$ zdravlje, 2(1), 65-74.

Jagić, S., i Jurčić, M. (2006). Razredno-nastavno ozračje i zadovoljstvo učenika nastavom. Acta Iadertina, 3, 29-43.

Juričić, M. (2006). Učenikovo opterećenje nastavom i razredno-nastavno ozračje. Odgojne znanosti, 2(2), 329-346.

Kevereski, LJ. (2011). Komunikacija u školi danas putokaz za sutra. Pedagoška stvarnost, LVII (5-6), 521-527.

Kostović, S. (2005). Vaspitni stil nastavnika. Novi Sad: Savez pedagoških društava Vojvodine.

Krstić, K. (2015). Attachment in the student-teacher relationship as a factor of school achievement. Teaching Innovations, 28(3), 167-188.

Lalić-Vučetić, N. (2008). Kvalitet komunikacije između nastavnika i učenika i primena podsticajnih mera. Zbornik Instituta za pedagoška istraživanja, 40(1), 122-136.

Mustafičić, N. (2013). Verbalna i neverbalna komunikacija kao najznačajniji faktor u kvalitetnoj interakciji nastavnik-učenik. Preuzeto 20. aprila 2020. sa http://www.quality.unze.ba/zbornici/QUALITY\%202013/ 69-Q13- 117.pdf 
Prušević-Sadović, F. R., i Šehović, S. F. (2017). Zastupljenost verbalne aktivnosti učenika u nastavnom procesu. Inovacije u nastavi, XXX (4), 116-124.

Radojević, T. (2015). Pedagoški aspekti razvijanja komunikacionih kompetencija učenika u osnovnoj školi (doktorska disertacija). Kosovska Mitrovica: Filozofski fakultet.

Shams, F., Khan, N., Zainab, B., Shah, K., \& Farid, N. (2016). Non-verbal communication and its effect on students at secondary level in District Buner, Pakistan. Language in India, 16(2), 59-66.

Spasenović, V. (2004). Prosocijalno ponašanje i školsko postignuće učenika. Zbornik Instituta za pedagoška istraživanja, 36, 131-150.

Sutiyatno, S. (2018). The effect of teacher's verbal communication and nonverbal communication on students' english achievement. Journal of Language Teaching and Research, 9(2), 430-437.

Šimić-Šašić, S. i Sorić, I. (2011). Kvaliteta interakcije nastavnik-učenik: povezanost s komponentama samoreguliranog učenja, ispitnom anksioznošću i školskim uspjehom. Suvremena psihologija, 14(1), 35-55.

Šimić-Šašić, S. (2011). Interakcija nastavnik-učenik: teorije i mjerenje. Psihologijske teme, 20(2), 233-260.

Zibar-Komarica, V. (1993). Neuspjeh u školi. Zagreb: Školska knjiga.

Zukorlić, M. S. (2016). Pedagoška komunikacija u funkciji razvoja socijalne kompetencije učenika. Inovacije u nastavi, XXIX (1), 92-104.

Zukorlić, M. S. i Osmanlić, I. A. (2017). Nivoi interaktivne povezanosti učenika i nastavnika u nastavi. Inovacije u nastavi, XXX (2), 172181. 